\title{
感情表出文
}

東 弘子†

本稿は,「まあ，嬉しい！」のような発話者が感情を思わず口にした「感情表出文」と はどのようなものか，感情主の制約のあり方と，統語的特徵から分析したものである. 感情述語の人称制約は 2 種類のムードに関わる問題である。一つは,「述べ立てのムー ド」，もう一つは「感情表出のムード」である。前者のムードを持つ「述べ立て文」に 生じる人称制約は語用論的なものであり，一人称感情主の場合が多いが，条件が整え ば他の人称も可能である。一方，感情主が一人称以外ではあり得ないような人称制約 を持つタイプの文がある，これを，感情表出のムードを持つ「感情表出文」と定義し た.

その上で, 感情表出文の統語的特徵について検討した結果, 感情表出文は, 述語が要 求する感情主や感情の対象といった意味役割を統語的に分析的な方法では言語化しな い，すなわち述語一語文であるという事実を明らかにした。

一語文では，言語文脈上に意味役割の值を参照することができないため，発話現場に 依存して決めるしか方法がなく, 感情主は発話現場の発話者, 感情の対象は発話時の 現場のできごとに自動的に決まる。よって，一語文は感情表出文のムードに適合する。 一方，意味役割を言語化した文は，意味役割を発話現場に依存する必要がないため， 発話現場に拘束されない。こうしたことから，感情表出文は述語一語文でなければな らないと結論づけた。

キーワード： 感情形容詞，文のムード，人称制約，一語文

\section{Exclamatory Sentence}

\section{HIROKO AZUMA}

This paper attempts to elucidate the nature of 'emotive sentences' like Maa, ureshii! ' Wow, how happy (I am)? in which the speaker involuntarily expresses his emotion, with special focus on the manifestation of experiencer subjects.

The grammatical person of the experiencer subject that an emotive predicate takes is constrained by the mood of the sentence in which it appears. On the one hand, if an emotive predicate appears in a sentence in 'the mood of the speaker's statement' , the person of its subject is only pragmatically controlled. While the first person is most often found, other persons are also allowed in certain pragmatic contexts. On the other hand, the first person is the only possibility in sentences in 'the mood of involuntary expression of an emotion'.

Furthermore, several syntactic tests reveal that predicates of sentences in the latter mood do not syntactically manifest either the experiencer or the source of an emotion. In other words, emotive predicates solely constitute sentences in this particular grammatical mood.

Put differently, since neither the experiencer nor the source of an emotion is realized in a one-word emotive sentence, the values of these implied arguments must be inferred from the context of utterance of that sentence. Consequently, the experiencer 
is automatically understood as the speaker, and the source as a concurring event in the same context.

KeyWords: emotive adjective, mood, person restrictio 2 , one word sentence

\section{1 まえがき}

現代日本語で「うれしい」「悲しい」「淋しい」「羡まし人」などの感情形容詞を述語とする 感情形容詞文には, 現在形述語で文が終止した場合, 平叙文の際, 一人称感情主はよいが二人 称，三人称感情主は不適切であるというような，人称の制的現象がある ${ }^{1}$.

(1) \{わたし/??あなた/?? 太郎 $\}$ はうれしい.

(2) \{わたし/??あなた/?? 太郎 $\}$ は悲しい.

このとき，話し手が発話時に文をどのようなものと捉えて述べているかを表す「文のムー ド」2によって, 感情形容詞の感情の主体（感情主）が, 貄し手である一人称でしかありえない 場合と, やや不自然さはあるものの文脈によっては, 二小称, 三人称の感情主をとることが可 能な場合がある (東 1997; 益岡 1997).

(3)(4)のように, 話し手の発話時の感情を直接的に表現している「感情表出のムード」を持 つ「感情表出文」((益岡 1991，1997）で「情意表出型」とされる文の一部)では，感情主は一人 称に限定される。「感情表出のムード」とは話し手が発話帱の感情を「思わず口にした」ような ものであり，聞き手に対してその発話内容を伝えようと中うつもりはあってもなくてもよいも のである3.

$†$ 愛知県立大学 非常勤講師, Aichi Prefectural University

1 本稿で言う「人称」とは,「人称を表す専用のことば」のことではない。

「話し手」か「聞き手」か「それ以外」かという情報である。よって, 普通名詞であろうと, 固有名詞であろうと, 多イ クシス専用の名詞であろうと, 言語化されていないものであろうと, 引れがその文の発話された状況において話し手を 指していれば一人称, 聞き手を指していれば二人称, それ以外であれれ三人称という扱いをする.

a. 太郎は仕事をしなさい.

b. アイちゃん，ご飯が食べたい. (幼児のアイちゃんの発言) a.の「太郎」は二人称, b.の「アイちゃん」は一人称ということである.

2 文のムードとは, 話し手が, 文を述べる際, どのような「つもり」すあるのかを示す概念である. 文を聞き手に対し てどのように伝えるか (例えば, 命令, 質問など) ということと共に, 貄し手が, 発話内容に対してどのように判断して いるか (例えば確信, 推量, 疑念など) も文のムードである。これを「作少ティ」と呼ぶこともあるが, 本稿では, こ ういった文の述べ方に対する概念的区分を,「ムード」と呼び, ムード办具体的に言語化された要素を「モダリティ」と 呼ぶ。例えば「明日は晴れるだろう.」という文では, 発話内容に対し推量していることを聞き手に伝え述べるという ムードを持つのが普通であり,「だろう」は推量を表すモダリティであ車。

3 感情表出文は,「まあ」「きやつ」「ふう」など, 発話者が自分の内面の感情を聞き手に伝達する意図なく発露する際に用 いられる感嘆語と共起することが多いことから, 聞き手への伝達を要 ないものであることが分かる.

きやっ, うれい.

ふう, つらい.

一方「さあ」「おい」「よお」など，聞き手に何らかの伝達を意図する然嘆語と共起した場合，感情形容詞述語文であっ ても，感情表出文にはならない。

さあ, 悲しい。

おい，寂しい。

ただし,「まあ」などの感嘆語は感情表出文にとって必須ではない. 
(3)まあ，うれしい.

（4）ええ憎い，憎らしい….人汃与ひょうを〔木下順二『夕鶴』〕

一方，客観的に捉えた発話内容を述べ，聞き手に伝え述べるという「述べ立てのムード」 ((仁田 1991) 第 1，2 章参照) を持つ「述べ立て文」((益岡 1997) で「演述型」とされる文) に おける人称の制約は弱い。一般的には，(益岡 1997(:4))で述べられている「人物の内的世界は その人物の私的領域であり，私的領域における事態の真偽を断定的に述べる権利はその人物に 専属する.」という語用論的原則により，(5)(6)のような感情を表す形容詞（益岡によれば「私 的領域に属する事態を表現する代表的なもの」）を述語にする文において「あなた」「彼女」に 関する事態の真偽を断定的に述べることは不適格である ${ }^{4}$.

（5）夫が病気になったら $\{$ わし/\#あなた/\#彼女 $\}$ はつらい.

（6）海外出張は $\{$ わたし/\#あなた/\#彼女 $\}$ には楽しい.

しかし，このような語用論的原則は，文脈や文体的条件 5 などにより，その原則に反した発 話でも許される場合があるのである。（7）は感情主を数量子化したもの，(8) は小説という文体 的条件による.

（7）海外出張は誰にでも楽しい.

（8）それをこさえるところを見ているのがいつも安吉にはたのしい.(中野重治 『むらぎも』）

こういった人称制約のタイプを語用論的な人称の制約とする.

(東 1997) では，前者のように人称が限定されるタイプの人称制約を「必然的人称指定」, 後者 のように語用論的に限定される人称制約を「語用論的人称制限」と呼び区別した. (益岡 1997(:2)) でも情意表出型と演述型の人称制限の違いを，後者のみが日本語特有の現象と捉え，区別する 必要を述べている.

しかし，従来の研究においては，その「感情表出（情意表出）のムード」がどのようなもの であるかということは明確に規定されておらず，また，どのように感情主が一人称に決定され るのかという人称決定のシステムも描かれてきていない ${ }^{6}$.

そこで，本稿では，以下の手順で「感情表出文」について明らかにしていく．

(I) 人称の制約が文のムードと関係して生じていることを確認する $(2.1)$

4 ここでは, 語用論的に不適切であると考えられる文を，\#でマークし，文法的に不適切であることをあらわす*とは区別 して用いる。

5 文体的な条件によって人称制約が变わるというのは，小説などにおいて一般的な日常会話と語用論的原則が異なってく ることから生じるものである. (金水 1989) 参照

6 (益岡 1997(:2))でも「悲しいなあ.」のような「内面の状態を直接 に表出する文の場合，感情主が一人称に限られる のは当然のこと」とされている. 
（II）感情表出文は，そのムードが述語主体を常に十人称に決定するものである ことを定義づける。(2.2)

(III) 感情表出文として機能し解釈されるためには十語文でなければならないこ とを主張する。(3)

(IV) 感情表出文のムードの性質から (III) を導き出す。

また，ここでは，人称制約を受ける部分を「が格（主格」」ではなく，「感情主」という意味 役割を伴うもので扱う。感情形容詞述語は「感情主」と「感情の対象」（時にはそれは「感情を 引き起こす原因」）を意味役割として必要とするが，人称の制約を受ける感情主は，ガ格と二格 とニトッテ格で表される可能性があるからである。

(9) $\{$ 私/\#彼 $\}$ は仕事が楽しい.

(9)の「は」によって鲶されている格を表わそうとすれば，三つの可能性があるが，どれも 意味役割は感情主であり等価である.

(10) a 私が仕事が楽しいコト

$\mathrm{b}$ 私に仕事が楽しいコト

$\mathrm{c}$ 私にとって仕事が楽しいコト

また，(10)a におけるが格「私が」「仕事が」で，人称中制約がかかるのは，感情主「私が」 だけであり，意味役割が感情の対象である「仕事が」には人称の制約がかかることはない. さらに，(9)の主題は，感情主であるため人称の制約があるが，(11）の主題「仕事は」には人称 の制約はない.

(11）仕事は\{私/\#あなた $\}$ は楽しい.

このようなことから，本稿では人称制約に関わる名詞句と述語との関係を意味役割で捉える.

\section{2 感情主の人称制約と文のムード}

先に，文のムードによって感情主の人称制約のあり方が違うことを指摘したが，ここでは， 人称の制約現象が, 文のムードと関係して生じているものであることを, 形容詞句の統語的な 位置付けから確認する。

まず，ムードを持たない統語的位置に形容詞句があるもきには感情主の人称の制約がないこ とから，人称の制約は，ムードを伴うことによって生じることを示す.

さらに，述べ立て文と感情表出文における感情形容詞长の人称の制約現象を比較し，両者の 人称制約は，全く性質の異なるものであることを主張する. 


\section{1 ムードを持たない統語的位置における感情主}

感情形容詞を述語とする文に，常に感情主の人称制約があるかというとそうではない. (12) 〜 (16)のような文には, 感情主の人称の制約はない。これらには, 文脈がどうであろうと, 語 用論的な制約もかからず，どの人称もあらわれ得る。

(12) [[よし子にとってはうらやましい]話]だ.

(13) こどもの成長は[[親にとってうれしい]もの]だ.

(14) [[あなたが悲しい] とき], 彼女なら慰めてくれるだろう.

(15) [[私が苦しい]の]は，あなたのせいじゃない.

統語構造上，形容詞句は名詞句の内部に現れ，(南 1993) の階層で言えばB類に相当すると ころにあると言える. 文のムードは南の階層のB類では担わない7.

(16)*[[よし子はうらやましいだろう] 話 $]$ だ.

(17) *[[太郎は花子の死が悲しくあるまい] の] は当然だ.

このように，文のムードと関わりのない統語的位置に，感情主と形容詞があるときには，感 情形容詞文に人称制約は全くないのである.

一方，ムードを担う文末に形容詞があったり，モダリティがムードを指定している文では人 称の制約が働く.

(18) \#よし子はその話がうらやましい.

(19) \#私はその話がうらやましいだろう.

よって，人称の制約現象は，明らかに，ムードとの関連のなかで生じている現象であること がわかる.

\section{2 人称制約のある文と文のムード}

感情形容詞文の感情主に人称の制約があると言っても，そのあり方は一元的ではなく，「語用 論的人称制限」と「必然的人称指定」があることは，1.まえがきにも述べた．それぞれについ

7 (南 1993) では, 様々な節の内部にどのような文の要素が含まれ得るかによって, 文の階層構造を示した. 代表的な例 をあげておこう。

・ナガラ節 (平行継続) : 程度副詞, ガ格以外の格, 動詞, ボイス, 尊敬などを含み得る $\rightarrow \mathrm{A}$ 類

美佐子は [ちらちらテレビを見ながら $\mathrm{A}]$ 勉強した.

*[美佐子がテレビを見ながら $\mathrm{A}]$, 良夫が勉強した。

・ノ二節：A類の要素, 場所の修飾語, 対比のハ, ガ格, ナイ, 夕などを含み得る $\rightarrow \mathrm{B}$ 類

[彼が [病院に行か $\mathrm{A}]$ ないのに B], 私だけ行くのはいやだ.

*[彼は [病院に行か A] ないだろうのに B], 私だけ行くのはいやだ.

- カラ節 : A 類, B類の要素, 主題, マイ, 名ロウなどを含み得る $\rightarrow \mathrm{C}$ 類

[彼は [病院に行く A] だろうから C], 私も準備しておこう.

題述関係はC 類の階層に属し，ここにおいて主題とムードが呼応している. 
てムードと人称の制約との関係を確認し，その上で, 感情表出のムードを定義しよう.

\subsection{1 語用論的人称制限一述べ立てのムードの文}

先述の (益岡 1997)において明らかにされたように, 速べ立て文において, 話者以外の感情 (私的領域に属する事象) を, 話者が断定的に述べることほ, 語用論的に避けられるべきことで ある。しかし，その原則が，文体，文脈的条件によって，啇用されていない例を見てみよう。

(20) シルレルの名を聞くことがもう僕には辛い. 小林秀雄『ドストエフスキー の生活』)

(21) それをこさえるところを見ているのがいつも安吉にはたのしい. ((8) 再掲)

(22) 榊山は嬉しかった. (檀一雄『花筐』)

(23) 「私，自殺まで考えたのよ.どう責任とってくれるの.」 「わかった，あなたはつらかった，それはわかったから，今日のところは引 き取ってくれ.」

(20)〜 (22) は小説からの引用であり，小説という文体すは自然な表現であるが，一人称感情 主の (20) 以外, 日常的な対話の場でこのような文は不自然である.また，(23) は話し手が聞き 手に抗議された内容をまとめて, 過去のコトガラとして強引に提示するような場面で用いられ

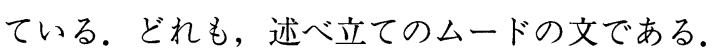

また, (益岡 1997) の原則とは別に, 三人称の感情主かもっとも適切だが, 文体, 文脈的条 件によって, 一人称, 二人称でも容認可能になる例もある|. これらは, 推し量り形式のモダリ ティが後接したものである.

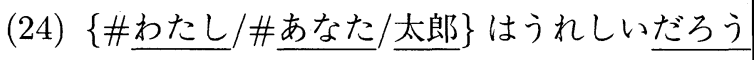

(25) $\{$ \#市たし/\#あなた/太郎 $\}$ は連敗が悔しいに兮がいない.

$(24)(25)$ は, 一, 二人称の感情主では, 普通不自然である.しかし, 条件節などによって仮 定の出来事であるという文脈的意味があれば，適切になる上うな性質のものである.

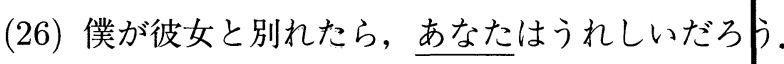

(27) 今はまだ自分の実力に自信がない。連敗し才も仕方ないと思う。しかし， 将来羽生善治氏のような栄光を手に入れたとして, その後名もない人に連 敗などしたら……そんなことになったら，わたしは連敗が悔しいにちがい ない.

8 本稿の立場とは異なり，感情形容詞述語が一人称の感情主をとることを基本と考えてきたような研究においては，三人 称をとる文は「人称制限解除」として, 先の 2.1 の条件と同等に扱われた. しかし, どの人称も問題なくとれる 2.1 の ものと，三人称をとりやすいこれらとは，当然別に扱うべきである. 
これら人称制約が生じることのある感情主は, どれも文の主題であり，(南 1993) の階層で はムードと呼応する階層（C類）のものである（註 7 参照）。そして，(20)〜 (27) の例はみな， 述べ立て文である。

述べ立てのムードを持つ文の語用論的な人称の制約のあり方は，(仁田 1991)(第二章) に詳し いが，そこでは次のような例があげられている9 .(例とその判定は (仁田 1991(：83-93))より。 ただし，仁田論文において語用論的な人称制約で不適切な文についても用いられている*を，こ こでは\#に書き換えた。)

(28) \{私/\#あなた $\}$ は母が恋しい.

(29) ?ほら，君，転んだよ。

(30)＃僕は彼を殴っただろう。

(31) \#君は頭が痛い\{だろう/らしい/かもしれない\}.

感情形容詞文の，文体，文脈的条件で変化する人称の制約も，こういった述べ立て文におけ る人称制限そのものである.

このように，文体，文脈的条件によって人称の制約の変化する感情形容詞文の人称の制約は， 感情形容詞文に特有の現象ではなく，述べ立て文全体に存在する，語用論的な現象なのである.

\subsection{2 必然的人称指定一感情表出のムードの文}

次に，常に感情主が一人称に決定されるような文をあげよう。

(32) 嬉しい。ねえ，しばらくでいいから，いっしょに連れて歩いて。（丸谷才一

『笹まくら』)

(33) ええ憎い, 憎らしい…人朲与ひょうを ((4) 再掲)

(34)「悲しいわ.」駒子はひとりごとのように呟いて (後略)(川端康成『雪国』)

これらの感情形容詞文の感情主は，言語化されていないが，話し手に決定している，これら の文が担っているのが感情表出のムードであり，「感情表出文」は，次のように定義されるであ ろう.

（35）発話者の発話時に生じる感情的状態を，客観的判断過程を通さず，直接的 に表現した文

しかしここで問題になるのは「直接的に表現」することの意味である．先行の研究におい て感情表出は以下のように定義されているが，その議論をたどり，扱われている例文を見ても， 「表出」することと「述べ立てる」こととの違いは鮮明でない.「表現時の感情」を単に述べるこ 9 仁田はこれらの人称を「が格」としているが，「主題の人称制約」とすべきであろう（(東 1997），本稿「まえがき」参照) 
とと「表出」することの本質的な違いについては説明されてきていないのである.

(寺村 1984(:349)):話し手のそのときの気持の直接的な表出

(益岡 1991(:80-81))

- 対話文の「情意表出型」:表現時において, 話し手の内面に存する感情・感覚や意 志の内容を情報として聞き手に伝える働きを持つ.

- 非対話文の「情意表出型」:表現主体の内面にある感情・感覚や意思を表すもの

(山岡 1997):発話時の話者の感情を直接表出する文.

述べ立てと表出とは, 以下のような点で, 明らかに異なる.

「述べ立て」文は, 発話者が, 何について述べるのか（文の主題）を多くの候補の中から選 び出し，それについて述べるものである，述べられるものが「発話者自身」であり，また，述 べる内容が「発話者の感情」であれば，一人称感情主についてその感情を述べる文になる。そ れは，三人称主題についての述べ立て文とムード的には何ら変わりない.「述べ立て」のムード の文においては，基本的にどんな人称も主題にできる10

(36) 私は試験がつらい.

(37) 太郎は試験がつらい.

(38)この自動車は古い.

一方「表出」は，ムードそのものが，発話者の感情を述べることを含み込んでおり，常に， 感情主は発話者，すなわち一人称に決定している，述べ立て文のように，何について述べるの かの選択の余地はない.

(39) つらい! (感情主=発話者 (一人称) )

こうしたことから，ここで「表出」というものを次のように定義する.

(40) 表出文：その文のムードが述語主体を常に一人称に決定するもの ${ }^{11}$

感情を表す述語としては，形容詞だけでなく感情動詞もある。しかし感情や感覚，心理を表 す述語であっても，動詞文では多くのものが(41)(42)のように感嘆語と共起しても発話者の感 情を表出する文にはならない. $(44)(45)$ のような一部の動詞のみ12, 感情表出のムードをもつ

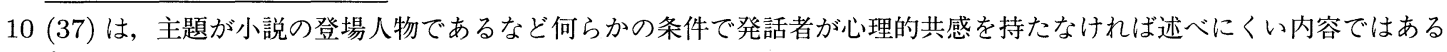
が.

11 同じ表出のムードである「意志表出」でも同様に, ムードにより動作主が決定している.

よし, 手術をしよう。(動作主=発話者 (一人称)

感情表出文と意志表出文の関係は次のようになる.

感情表出文：述語主体が感情主（例：うれしい!)

意志表出文：述語主体が動作主（例: 明日こそ宿題をやろう!)

12 註 14 にも引用したように, 多くの動詞は, 話し手自身の感情を直接表出するのには用いられない. 
ことができる13.

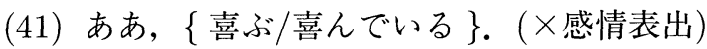

（42）まあ，\{悲しむ/悲しんでいる \}.（×感情表出）

(43) \#私は合格を $\{$ 喜ぶ/喜んでいる $\} .(\times \text { 感情表出 })^{14}$

(44) ああ, 腹が立つ. (感情表出)

(45) まったく，イライラする. (感情表出)

感情表出文における人称制約は，感情形容詞文と，一部の感情動詞に特有の現象なのである。 以上，本章で論じた点をまとめると以下のようになる。

（46）人称の制約のあり方は，形容詞句（一部動詞句）の統語構造上の位置と深 く関係している.

$$
\left\{\begin{array}{cl}
\text { ムードに関係ない形容詞句 (南の } B \text { 類) } & \text { : 人称制約なし } \\
\text { ムードに関係ある形容詞句 (南の } C \text { 類 }) & \left\{\begin{array}{c}
\text { 述べ立てのムードの文 } \\
: \text { 一般的な語用論的原則から生じ } \\
\text { る人称制約 }((24)(25)) \\
\text { 感情表出のムードの文 } \\
: \text { ムードによって人称が決定 } \\
\text { 感情形容詞と一部の感情動詞に } \\
\text { 特有の現象 }((32) \sim(34)(39))
\end{array}\right.
\end{array}\right.
$$

次章ではその感情表出文について，統語的特徴を明らかにする.

13 感情動詞の表出文については山岡 1997 参照. ただし山岡の言う「感情表出」には「述べ立て文」も含まれている. 山岡の示すものの中で本稿の定義に一致する感情動詞は(45)(46)のほか, 「頭に来る」「困る」「むかつく」「ドキドキす る」「わくわくする」など，聞き手不在で使用できる感嘆語「ああ」などと共起できる動詞である，山岡の挙げる「疑 う」「照れる」「気が晴れる」「憎む」などは表出文にはならない.

14 (寺村 1982(:143)) には「動詞による感情表現のほうが」形容詞より「より客観的，物語り文的」とあり，「動詞表現は， 話し手自身の発話時の気持ちを直接的に表出する表現ではない」としている．そのため，述べ立て文としての語用論的 な人称の制約となるが，この場合，二人称だけでなく一人称も述べにくい，一人称の感情であれば，動詞で述べるより も形容詞で述べるほうが語用論的に適切だからである.

\{\#わたし/\#あなた/太郎\}は合格をよろこんでいる.

\{\#わたし/\#あなた/太郎 \} は別れを悲しむ. 


\section{3 感情表出文の統語的特徵}

\section{1 表出文であるための条件 $(1)$ - 述語の形態と条件節}

感情表出が，発話時の感情を表出するということをふまえれば，まず，述語が過去形であっ たり ${ }^{15}$ ，述べ立てのムードをあらわすモダリティが文末にあれば，表出文でないことは明らか である.

(47) 私は淋しかった. (夏目漱石『こころ』)

(48）無性に悲しかった. (新田次郎『孤高の人』)

(49)*ああ，\{うれしかった/哀しかった\}.

(50) あなたも辛いだろうが，私も辛いのだよ」(田辺聖子『新源氏物語』)

また，現在形であっても，(51)(52)のように否定形では感情表出のムードは持なない. 否定 というのはそもそも，肯定される事態を想定したその上で，否定するという形式である．感情 表出のムードは前述したように「発話時の一瞬に生じた感情的状態を客観的判断過程を通さず 直接的に表現」するものであるから，一旦想定した事態を否定するというような判断過程が入 りこむ余地はなく, よって, 否定形は感情表出のムードに馴染まないのである ${ }^{16}$.

(51)*まあ，嬉しくない！

(52)＊ああ，淋しくない！

よって，否定形は述べ立てのムードになり，人称の制約も必然的なものではなくなる.

(53) 妹の店で飲んでも\{わたし/\#あなた/\#太郎 $\}$ は楽しくない.

(54)「お万阿，そなたのお喋りを聞いていると〔中略〕これはおもしろいわい」

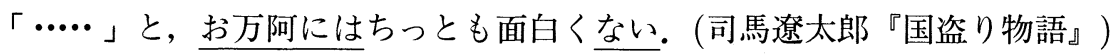

また，条件節が前接した場合も，発話時の感情表出のムードにはならない，条件節で提示し た内容が発生した時においての感情を述べることになるからである.

(55) もし君が来てくれたら嬉しい. (福永武彦『花の草』)

(56) スキーで雨に降られるとつらい.

本節で確認した感情表出文になるための条件は以下の通りである.

15 ただし,「ああ, \{怖かった/おいしかった/つらかった \}.」のように，過去形であっても感情表出文となるものもある. これらは感情を引き起こす原因が消失すればその感情も消失するような夕イプのもので, 原因が消失した直後の発話と してこのような過去形の表出文が成立するようである。詳細は別稿に譲る。

16 当然の事ながら,「つまらない」「やりきれない」など, 固定化した表現は, 否定形ではない. 
<事実 $1>$

（I）述語が現在形で，並べ立てを表すモダリティが付加しない

(II) 述語が肯定形

(III) 条件節が前後しない

\section{2 表出文であるための条件 ( 2 )-無題文}

3.1 で確認した事実は, 感情表出文となるための必要条件であり, それだけでは表出文の特 徵を記述したことにはならない. 本節ではさらに感情表出文の統語的特徴を示す。

(益岡 1997(:2))には，情意表出型の文の説明として次のような記述がある.

(4) 悲しいなあ.

このような場合, 感情主は一人称に限られるので, 一般に省略される.

(5)？僕は悲しいなあ.

益岡は，例 (5)に「?」を付しているが，これが表出文なのか述べ立て文なのか，明確には 示されていない。この文が述べ立て文であれば，「僕」について述べる述べ立て文であり，不自 然さはない.しかし，例文 (4)の「悲しいなあ.」が益岡の言うように「感情主が一人称に限ら れる」ものであるのなら，こちらは感情表出文である。（4）と同じ表出文として扱うのならば， 「僕は悲しいなあ.」という文は表出文ではありえないので,「?」ではなく「*」でなければなら ない，なぜなら，主題文は「主題について何かを述べる」文であり，主題は述べ立て文で用い られるものだからである。

感情表出文「悲しいなあ.」と述べ立て文「僕は悲しいなあ.」は，ムードの異なる文である ことから，益岡のように「一般に省略される」と記述するのは誤りである.

先行研究において「感情表出文」として提示された文で, 客観的な判断過程を含まず「直接 表出」した感情主の人称が一人称に決定しているのは次のようなものであり, どれも無題文で ある。

(57) さびしいな. ((寺村 1984)より)

(58) 哀しいね. ((益岡 1991)より)

(59) ああ，腹が立つ。((山岡 1997) より)

しかし, 筆者の研究も含め, 従来のいくつかの研究において「感情表出文」とされた例の中 には, 主題を持ち, 発話時の発話者の感情を表出したものとは思われないものがある.

(60) ぼくは蛇が怖い。((寺村 1973)より)

(61) 私はすしが食べたい. (同上)

(62) いや，野暮なことを言って，わしは恥ずかしい. (木山捷平『長春五馬 路』)((東 1997)より) 
それぞれの主題に話者以外の感情主をあてると，確かに，不自然な文にはなる，しかし，こ れらは，先の 3.2 で確認した語用論的な制約によるものである。それらを述べてもよいような コンテクストさえあれば，決して非文ではない.

（63）拓也は蛇が怖い，慎吾は雷が怖い，正広は暗闇が怖い. まったくここには怖がりばかりいるなあ.

また，感情主以外の主題があっても同様に述べ立て文である ${ }^{17}$.

(64）人間のことを想うのは哀しい。(大仏次郎『帰京』)

（65）ゆらりゆらり輪を描いて浮いてゆくむらさき色のけむりは愉しい.（林芙美 子『放浪記』)

(66) この店のコース料理にはデザートが二品ついてくるのがうれしい.

（67）バスは時間が不定期で困るよ。(赤川次郎『女社長に乾杯』)（(山岡 1997） より)

これらの文における感情主は，必ずしも発話者とは特定できない，generic な解釈がなされ る文である.「誰にとってもその感情が引き起こされるような状態」であることを述べている文 なのである18.

また，(64)〜 (67) には「〜にとって」という形式で, 感情主を挿入することができるが，感 情表出文には挿入できない.

(68) 人間のことを想うのは $\{$ 私/彼女 $\}$ にとって哀しい.

(69)*わあ，私にとって哀しい!

よって，(68)のよjに感情主が抻入できる $(64) 〜(67)$ の文は述べ立て文であるといえる.

もちろん，(70)(71)のように文脈上，表現されていない感情主が一人称であると考えたほう が妥当なものもあるが，これらも状態を叙述する述べ立て文であることには变りない，同様の ことは属性形容詞文 $((72))$ にもある。

（70）今日は母の手蹟を見るのがはなはだ嬉しい.(夏目漱石『三四郎』)

(71) (八月 $\times$ 日)

よそへ行って外のカフエーでも探してみようかと思う日もある。まるでア

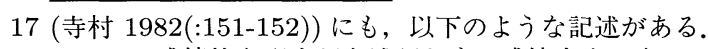

感情的な形容詞を述語とする感情表出の文, $\mathrm{X}$ ハガ (形容詞)

の, X (感情主) が文の背後にかくれ，Y，つまり形容詞で表される感情の対象が文の主題となって，Y八(形容詞）と なると, それは, 一一般にYがこれこれの感情を引き起こすような性格を持ったものだ」という, 品定め文の一種となる.

18 (寺村 1982) にも,「それ（=感情主の名詞句：引用者補）が文中になければ, その品定めが「一般に, 誰にとっても」 そうだという意味に解釈される」とある。 
ヘンでも吸っているように，ずるずるとこの仕事に溺れて行く事が悲しい. (林芙美子『放浪記』)

(72) 私は暗記が苦手だ。特に英単語を覚えるのは難しい.

また，本来は主題があるが，文脈上省略されて鿵れている文の場合も，やはり感情表出文に はならない。次の例で，下線の文はそれぞれ「私は」「加恵は」という主題が省略されており， 述べ立て文である。

(73) 本当にいやないたずらね. 嘘と分かっていても腹が立つわ. (赤川次郎『女 社長に乾杯』)((山岡 1997)より)

(74) 加恵はそれを娘を丧った悲しみが躰にも響くのだと思っていた。目 を押え，拭いながら，加恵は前々通りに家の中の雑事を片付けて いた。しかし，夜になるとしみじみと娘が恋しかった。於継はそれ を身を切り裂きたいようであったといったが, 同じ悲しみでも加 恵の性格ではそういう烈しさよりも全身の力が脱け落ちている. 苛立たしいほど虚しくて，どうすることもできないほど淋しい. 加恵は自 分の瞼にじっとりと滲み出るのは, 涙ではなくて血なのではないかと思っ ていた。(有吉佐和子『華岡青州の妻』)

以上の観察から，次のことが言える。

<事実 $2>$

感情表出文は，主題を持てない。 19

\section{3 述語のみの文 (統語的に未分化の文)}

では，3.1の条件を満たし，無題文であれば，感情表出文なのであろうか. 元来感情形容詞文は，感情の対象または感情主をとり，形容詞句を作るものである.

(75) この授業がつまらない(のは先生のせいだ。) (感情の対象)

(76) 私が悲しい(ことをみんなは知らない。)

(感情主)

(77) 彼にとって 社長との再会がうれしい(はずはない.) (感情主)（感情の対象)

ところが，先の感情表出文の例 $((57) \sim(58))$ は，無題文であるだけでなく，そのどちらをも 19 同じ表出文である意志表出文も同様の特徴を持つ. 意志表出文において「は」は常に「対比」の意味を持つ.（(東 1997) 参照) 
言語化していない ${ }^{20}$ 。(例文再掲)

(57) さびしいな.

(58）哀しいね.

(59) ああ, 腹が立つ.

このように感情主も感情の対象も言語化しない文が感情表出文となる，意味役割からすれ ば, 感情形容詞文は, 「感情主」「感情の対象」をとる可能性がある。しかし, それらの意味役割 を助詞を伴って言語化した文は，感情表出文にならないのである.

感情主や感情の対象を言語化した例において, (40)の定義のように, 感情主が一人称に決定 しているかどうか確認してみよう。

(78) a わたしが淋しい.

bわたし, 淋しい.

（78）は, 感情主を言語化した例である，a b それぞれについて, 感情主が発話者に決定して いるか否か確認しよう。

次のよjな文脈で，感情主を訊ねる質問文の答えとしては， $\mathrm{a}$ を用いるのが適切であり， b は不適切である。

(79) 問：「一体誰が淋しいの?」

答：a「わたしが淋しいの.」

b\#「わたし, 淋しいの.」

このことは，(79）a は，感情主が決定していない際に用いる形式で， b は感情主が決定して いる形式であることを示している，aは感情主として「わたし」以外の他の候補もあり得る形 式だからこそ，この文脈で自然なのである，bは，このような文脈には現れない，それ以前の 文脈とは無関係に, 唐突に発話されるものである。すなわち, a のように感情主がが格で表さ れた文は感情表出文ではなく, bのように無助詞の場合, 感情主が一人称に決定している感情 表出文であると言えるであろう.

また，(80)〜 (83) は感情の対象を言語化したものである，それぞれ，aは助詞を用いて感情 の対象をあらわし, bは無助詞である。これらにおいて, 感情主の人称が, 発話者に決定して いるかどうかを確認しょう。

(80) a 芝漬けが食べたい.

b芝漬け，食べたい。

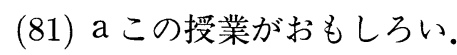

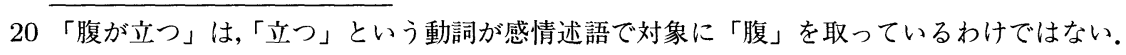




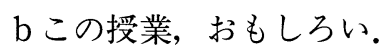

(82) a 先生と会えたから嬉しい.

b 先生と会えた，嬉しい。

(83) a 卒業できなくてつらい.

b卒業できない，つらい。

次のような文脈での問の答えとしては，a を用いるのが適切であり， b は不適切である.

(84) 問：「\{あなた/あなたの妹 \}は一体何が食べたいの？」

答：a 「芝漬けが食べたい.」

答：b\#「芝漬け，食べたい.」

(85) 問：「\{あなた/あなたの妹 \} はなぜ嬉しいの?」」

答：a「先生と会えたから嬉しい.」

答：b＃「先生と会えた，嬉しい.」

$\mathrm{a}$ の形式は，それぞれの問で示された主題を受けて，答えているものである．省略されてい る主題を示せば，それぞれ次のようになる。

(86) \{私/私の妹 $\}$ は芝漬けが食べたい.

(86) $\{$ 私/私の妹 $\}$ は先生と会えたから嬉しい.

ところが $\mathrm{b} の$ 形式は問に対する答として不自然である。もしこのような会話の流れの中で b のように発話したとすれば，問を無視した独白という印象を与える，bの形式では問で提示さ れた主題を受けることができず，感情主は発話者に決定しているのである，すなわち，(80)〜 (83)のbは，表出文ということになる.

しかし，無助詞であれば常に表出のムードを担うわけでもない．第三者が引用した例を見て みよう。

(88)「芝漬け食べたいって.」

「誰が?」

「太郎が.」

(89)「わたし，淋しいって」

「何が?」

「彼がいなくなったことが.」

こうした会話が成立することから，引用された「芝漬け，食べたい」「わたし，淋しい」の 感情主は一人称と限らず，表出文でないことが分かる，(88)のように感情の対象に助詞を添え 
ないものは「って」という形式で間接引用されれば，表出文ではなく ${ }^{21} ，(89)$ のうに感情主 に助詞を添えないものは直接引用になり,「わたし」は発話者ではない.

このことから，感情主や感情の対象を無助詞で表すことは，感情表出文であるための必要条 件であるが，十分条件ではないことが分かる。すなわち，表出文で感情の対象を言語化しよう とするのであれば，助詞を伴うことはできないということである ${ }^{22}$.

こうしたことから，次のことが言える.

<事実 $3>$

感情表出文では，意味役割として存在する感情主や感情の対象を格を伴った形で表現す ることはできない.

\section{4 本章のまとめ}

以上，本章で見てきた感情表出文に関する事実を確認すると次のようになる.

（I）現在形，肯定形述語であり，並べ立てのモダリティや条件節が付加されない.

(II) 無題文である.

(III) 意味役割を格を伴う形でとらない.

上記より考察すると，感情表出文では，感情主や感情の対象を，統語的に分析的な方法では 言語化しないと言える。「まあ，わたし，うれしい.」というのは，表記上読点を子ればこれだけ 全体で一文であるが，「まあ。わたし，うれしい.」と句点をふつた三つの文と何ら変わりはない。 すなわち，感情表出文は，感情主や感情の対象をとらない一語文であると言える ${ }^{23}$.このこと から，次のような仮説を立てる。

$<$ 仮説 $>$

（I）感情表出文では，感情主や，感情の対象を言語化しない。すなわち，述語 のみの一語文でなければならない.

(II) 仮に言語化するとしても，格関係や，題述関係など，統語的に分析的な方 法をとってはいけない。

発話時の感情を直接表出する感情表出文がなぜ，述語一語文でなければならないのか，この 仮説を次章において検証する.

21 表出文であることを明らかにするために，感動詞を添えると，間接引用にはならず直接引用になる，感情主は当然引用 元の発話現場における発話者である。

「ああ芝漬け食べたい」って。

22 動詞文でも同様である。「僕が子供にイライラする.」「ああ, イライラする! (表出文)」

23 一文でこのような特徴を満たしていても, 文脈上, 感情主や感情が「省略」された場合, 感情表出文でない.「先生, 今 回の受賞のお気持ちを聞かせて下さい.」「(わたしは）(受賞が)とても嬉しいわ.」 


\section{4 感情表出文はなぜ一語文か}

前章では，述語のみの文が，感情表出のムードを持つことができるという事実を確認した。 本章では，表出文はなぜ一語文でなければならないのかを述べる.

\section{1 一語文の意味決定}

まず，本来とるべき意味役割を持つのにそれを言語化せず，一語文として表現される文が， どのように意味決定されるのか，その仕組みを考察してみよう.

一語文の用法に関しては (尾上 1998) の研究があり, 特に名詞一語文について詳しい分析が なされている。その中で，発話が名詞一語であることを本質的に必要としているのは「存在一 語文」と名付けられたものだけであるとしている24.「存在一語文」とは，現場における，遭遇， 発見の叫びとしての一語文であり，次のように分類されている ${ }^{25}$.

・ 存在承認：遭遇対象の名前を叫ぶことによって遭遇の際の急激な心的経験 そのことを語るもの

「とら!」(虎と遭遇した驚嘆を驚きとして発話する)

・ 存在希求：希求対象の名前を叫ぶことで希求感情そのものを結果的に表現 するもの

「水!」(砂漠で必死に水を求める)

これら存在一語文は,「述べないことによってこそ文であるという特殊な文表現

(尾上 1998(:907))」であるが，なぜそれらが驚嘆や希求を表す文になるのかということについ て，尾上では次のように説明している。

(前略) A 〈存在承認〉一語文と B 〈存在希求〉一語文は, 「それがある」こと,「それを求め る」ことを、「それ」の名を叫ぶことによって表現してしまう発話である. (中略) イマ・コ コにあるものが急激に話し手の心を覆ってしまったとき，その心的経験を何らかにことば に発散しようとするなら話し手はそのものの名を叫ぶしかない.これがA 1 《発見・驚嘆》 一語文である。また，イマ・ココにないものが話し手の心をイマ・ココで切実に充満する とき，その心的経験をことばにするなら，そのものの名を叫ぶ以外にない。これが $\mathrm{B}$ 《希 求》一語文にほかならない. (中略) 対象の名を呼ぶことによってのみ果たされる表現とは, 言ってしまえばイマ・ココの圧倒的な存在の承認である。(後略)

すなわちこれらの一語文は，発話現場（イマ・ココ）との関係が義務的であるということで ある。そして, 発話現場の状況と,「叫ばれた名詞」との関係によって, その発話の解釈は決定 する.

では，本稿で扱っている感情表出文としての一語文はどのような原理で表出文になるのであ ろうか.

24 他にも名詞一語文はあるが, それらは主述的に展開されうる文形式の一部が省略されて一語文になったものであるとさ れている.

25 (尾上 1998) では, 存在承認, 存在希求それぞれがさらに, 喚体的なものと伝達的なものとに下位分類されている. 
感情表出文は, 名詞一語文ではなく述語一語文である ${ }^{26}$. しかし，前章で述べたように，一 語文が感情主や感情の対象を言語化しないからと言って, 感情主や感情の対象そのものが存在し ないわけではない。次の例では, 感情主は発話者, 感情の対象は（）内に記したものであろう。

(90)わあ，おもしろい. (発話者の眼前の出来事)

(91) ふう，淋しい. (発話者の心中に想起されている出来事)

(92) はあ，つらい. (発話者にふりかかっている事実)

(93) ううん，食べたい. (発話者の眼前のもの)

これら感情主，感情の対象という意味役割に相当するものは，発話現場に依存して (もしく は拘束されて) 解釈が決定している.

その仕組みは以下のようである. 一語文は, 感情主, 感情の対象といったものが統語的に存 在しない. 故に, それた意味役割に対し, 言語文脈上の要素を参照して值を振り当てることが できない，そこで, 発話現場に存在する感情主 (発話者), 感情の対象 (目前の出来事など) に, 一義的に決定するのである。

図示すると，(90)のような一語文が発話されたとき，発話と発話現場の関係は，図 1 のよう である。

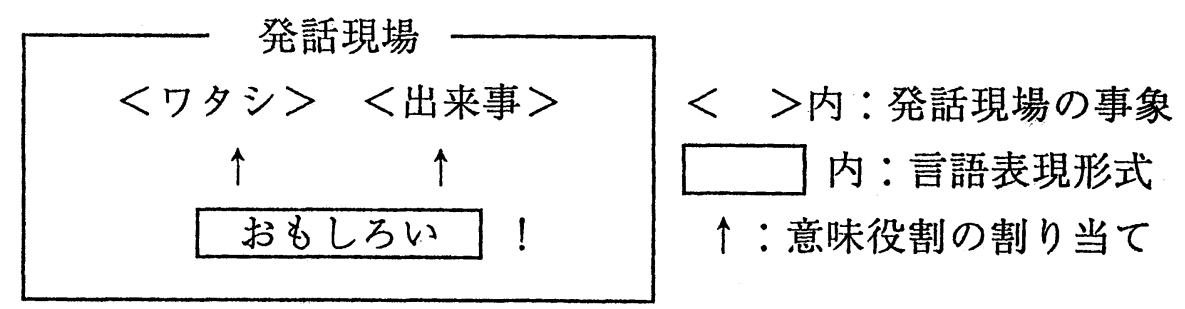

図 1 発話と発話現場の関係

述語一語文の意味決定の仕組みは以下のようにまとめられる.

(94) 述語一語文では, 述語の要求する意味役割は発話現場から探し出される.

一語文であることで，発話現場の感情主（発話者）, 発話現場の感情の対象（ものや出来事） に自動的に決定するのである.

このように述語一語文も発話現場と切り離せないものである. 分析的に表現しないことで， 発話現場とのつながりを絶対的なものとしているのである.

26 繰り返しになるが, 尾上の扱った「存在一語文」と同様，感情表出文は文中の他の要素があってはならないものである. 省略されているのではない. 


\section{2 一語文と文のムード}

述語一語文では，述語の要求する意味役割に相当するものを言語文脈上認定できないため， 発話現場から探し出し決定することを前節で確認した，それは，感情表出文が「発話時の発話 者の感情」を表出するものでなければならないことに適合する。 ${ }^{27}$

一方，前章で立てた仮説を検証するために，意味役割を分析的に言語化した表現が，表出文 になれないことを示そう。

助詞を用いて分析的に表現するとき，言語化される感情主や感情の対象は，統語的に存在す るので，発話現場のものである必要はない。

(98) 彼には出張中のK先生の授業がおもしろい.

(99) 亡き祖父は息子に先立たれてつらかった.

このように発話現場に縛られない表現が可能である，仮に発話現場のものを同様に言語化し ていたとしても，発話現場との直接的な関係は絶たれ，言語表現として客観的に対象化される.

(100) 私には今受けているこの授業がおもしろい.

(101) 僕は息子に先立たれてつらい.

「私」や「授業」が，発話現場のものであったとしても，助詞で関係づけている以上，言語 化された世界での関係を示すだけであり，現実世界とのマッチングは表現された名詞が行うの で，発話現場への直接的な值の参照は必要ないのである。意味役割は，言語化した世界で割り 当てられる。言語表現という閉じた世界の中で，何が何に対してどうである，どうするなど， 述語が要求する意味を満たす形で，関係づけているのである。これが一般的な文の述べ方で， 「述べ立て文」であることは言うまでもない。

こうした分析的な表現では，場面の状況や発話者との直接的な結びつきがないため，感情主 の制約も，一，二，三人称のいずれからも選ぶ可能性がある中で，語用論的原則により一人称 が選択されるということになるのである.

このような事実は，(山田 1908, 1936)の「喚体の文」が「非分解的である」(山田 1908) ${ }^{28}$ と いうことと一致する.山田の理論を現代日本語研究に継承するために再解釈したものとして, (尾上 1986; 堀川 1996) などがあるが，両者とも，喚体と述体を区別する要因の一つとして「現

27 述語一語文であれば，常に「感情表出」になるわけではない，場の状況や述語の意味に応じて，様々なムードが出現す る可能性がある。が，基本的に，テンスの分化のない述語一語文は，発話現場に存在する世界に直接意味役割を求めた 発話になるのである．例えば「壊す.」という発話は，発話現場の 2 つの動作主（話し手と聞き手）のどちらをとるかに よって，2 種類の文のムードを持つ可能性がある.

「壞す.」動作主 $\rightarrow$ 話し手 $\rightarrow$ 意志表出のムードになる

$\rightarrow$ 聞き手 $\rightarrow$ 命令のムードになる

28 (山田 1908(:1209)) には以下のよjにある（引用者により漢字を新字体に改めた）「元来喚体句は直感的のものにして， 他に之を伝子るに又直感を以てするものにして決して解せしむる目的にあらず. 感ぜしめむが目的なり. 感動は直感的 にして非分解的のものなり．然るに之を解釈すといふ直に了解作用の乗ずる所となりて，こ、に分離思考によらざるべ からず，この故に一旦解釈すればすでに喚体文にあらず.」 
場性」をあげている，喚体の文は現場性をもち，述体の文は現場からの独立性が特徴的である という，分析的でない感情表出の表現は，現場とのつながりにおいてしか成立しえない，まさ しく喚体の文と言えるのかも知れない29. 以上のことから，次のような結論を出す. $<$ 結論 $>$

一語文は，意味役割を発話現場から直接的に決定しなければならず，そのことと発話時，発 話者, 発話現場に拘束された感情表出のムードは適合する.

一方, 統語的に分析的な文は, 統語的に表現された要素の存在から発話現場には拘束されな いため，発話時，発話者の感情のみを表す感情表出文には不適切である.

よって，感情表出文は述語一語文でなければならない。

\section{5 むすび}

本稿での主張を順次まとめると，以下のようになる。

(I) 統語構造上の位置から感情形容詞文の人称の制約をみると, 文のムードに関係のある階 層に人称の制約があらわれる。

（II）感情表出のムードの文においては，感情主が一人称に限定され，他の感情主が選択され る余地はない.

(III) 感情表出文は, 発話現場から直接意味役割を捜し出す, 述語一語文でなければならない.

このように本稿では，感情表出文を述べ立て文から分ける明確な定義づけをしたことにより， 表出文が述語一語文であるという統語的特徴を示すことができた。 また，なぜ，感情表出文が 一語文という統語的特徴を持つのかについて, 一語文の意味役割決定のシステムを描くことに より，表出のムードとの意味の適合性があることを明らかにした.

$<$ 参考資料出典 $>$

中村 明 1979 『感情表現辞典』六興出版

C D - R OM版新潮文庫の 100 冊 新潮社版

29 ただし(尾上 1986) では喚体の文の特徴として「ことばになるのは遭遇対象, 希求対象のみで, 心的経験・心的行為

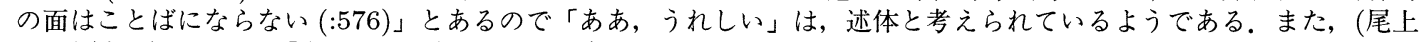
1998)(注 2 ) において「あつい!」なども述体の側に位置づけると述べている. (山田 1908)でも，現代語で「ああうれ しい」にあたる「あな, うれし.」は「感覚の言語的発表」であり, 喚体には近いがあくまでも述体の文であると分類さ れている. 


\section{参考文献}

東弘子 (1997). “日本語における人称とムードの一致.”『南山国文論集』21（南山大学国語学国 文学会) pp. 7-25.

堀川智也 (1996). “現代語における喚体的表現について."『名古屋大学日本語・日本文化論集』,4, pp. $27-40$.

金水敏 (1989). “「報告」についての覚書.”『日本語のモダリティ』（くろしお出版）pp. 121-129. 益岡隆志 (1991).『モダリティの文法』（くろしお出版）.

益岡隆志 (1997).“表現の主観性.”『視点と言語行動』（くろしお出版）pp. 1-11.

南不二男 (1993). 『現代日本語文法の輪郭』（大修館書店）.

仁田義雄 (1991). 『日本語のモダリティと人称』（ひつじ書房）。

尾上圭介 (1986). “感嘆文と希求・命令文一喚体・述体概念の有効性一.”『松村明教授古稀記念

国語研究論集』(明治書院) pp. 555-582.

尾上圭介 (1998). “一語文の用法一イマ・ココを離れない文の検討のために一”『東京大学国語 研究室創設百周年記念国語研究論集』(汲古書院) pp. 888-908.

寺村秀夫 (1973). “感情表現のシンタクス.”『月刊言語』2-2, 『寺村秀夫論文集』（1993くろし お出版），3-16 再掲 pp. 98-106.

寺村秀夫 (1982). 『日本語のシンタクスと意味』（くろしお出版）.

寺村秀夫 (1984). 『日本語のシンタクスと意味』(くろしお出版）.

山田孝雄 (1908). 『日本文法論』（宝文館出版）。

山田孝雄 (1936). 『日本文法学概論』（宝文館出版）。

山岡政紀 (1997). “感情表出動詞の状態性一感情形容詞との違いなどを中心に.”第 10 回日本語 文法談話会発表資料.

\section{略歴}

東 弘子： 1997 年名古屋大学大学院博士課程後期満期退学. 博士（文学). 以 後, 大学非常勤講師として国語学, 言語学, 日本語などを担当. 日本語学 (主に文法) 専門. 言語処理学会, 国語学会, 関西言語学会会員.

(1997 年 10 月 8 日受付)

(1998 年 1 月 27 日 再受付)

(1998 年 12 月 24 日 採録) 